\title{
INFLUENCE OF DEPTH ON THE GROWTH OF THE SEAWEED GRACILARIA BIRDIAE (RHODOPHYTA) IN A SHRIMP POND
}

\author{
OLIVEIRA, V. P. ${ }^{* *} ;$ FREIRE, F. A. M. ${ }^{2}$ \& SORIANO, E. M. ${ }^{1}$ \\ 1 - Departamento de Oceanografia e Limnologia - Universidade Federal do Rio Grande do Norte, \\ Brasil \\ 2 - Departamento de Ciências Animais - Universidade Federal Rural do Semi-Árido, Brasil \\ *Contact author: viniciusperuzzi@gmail.com
}

\begin{abstract}
Oliveira, V. P.; Freire, F. A. M. \& Soriano, E. M. 2012. Influence of depth on the growth of the seaweed Gracilaria birdiae (Rhodophyta) in a shrimp pond. Braz. J. Aquat. Sci. Technol. 16(X): 33-39. elSSN 1983-9057. This study evaluates the influence of depth and environmental parameters on the development of Gracilaria birdiae Plastino \& Oliveira (Gracilariaceae) in an organic shrimp pond. The macroalgae was cultivated on modules placed at three depths (surface, 10 and $20 \mathrm{~cm}$ depth). Growth rates were measured weekly based on variation in fresh weight during 35 days. G. birdie showed the greatest productivity $(35.7 \%)$ at $10 \mathrm{~cm}$, followed by $20 \mathrm{~cm}(33.4 \%)$ and surface $(25.3 \%)$. Average SGR values were $0.36 \pm 0.57 \% \mathrm{~d}-1$ (surface) $0.38 \pm 0.96 \% \mathrm{~d}-1(10 \mathrm{~cm})$ and $0.38 \pm 0.54 \% \mathrm{~d}-1(20 \mathrm{~cm})$, over the study period. The biomass variation of $G$. birdiae showed significant difference among the three depths. The correlations generated by multiple regressions demonstrated that analyzed environmental parameters explain from 62 to $67 \%$ of G. birdiae growth.
\end{abstract}

Keywords: Macroalgae, cultivation, environmental factors.

\section{INTRODUCTION}

In recent years intensive aquaculture has increased significantly worldwide (Naylor et al., 2000). In Brazil, the most advanced area of aquaculture is shrimp farming, which is considered one of the most economically important activities in the Northeast of Brazil (Nunes et al., 1997). Despite this promising picture, the expansion of aquaculture has been associated with the eutrophication of coastal ecosystems. This process can lead to enhanced sediment metabolism, anoxia, and others environmental variations that can also affect the benthic fauna and flora (Angel et al., 2000; Neori et al., 2007). These are direct consequence of the accumulation of organic material from the wastewater of aquatic organism cultivation system.

Recently, world shrimp farming has been searching for new methods to achieve sustainability and minimize the impact of eutrophication (Chopin et al., 2001). Aquaculture with seaweeds has been suggested as a viable solution for the problems caused by excessive waste in coastal areas. Seaweeds turn the available nutrients ( $\mathrm{N}$ and $\mathrm{P}$ ) into composites necessary for their development, improving water quality for cultivated animals and reducing nutrient concentration in the environment (Troell et al., 2003).

Seaweeds belonging to the genus Gracilaria Greville (Rhodophyta) are the most promising in integrated farming. This is because of their ability to achieve high biomass, significant commercial value of their derivatives and substantial potential as nutrient bioremediation agents (Msuya \& Neori, 2002; Tyler \& McGlathery, 2006; Marinho-Soriano et al., 2009). Despite the experience obtained in different studies, the cultivation of Gracilaria in integrated systems is still difficult in theory and practice (Marinho-Soriano et al., 2002; Buschmann et al., 2008). Limitations in acclimation, nutrient absorption, photosynthesis and various abiotic factors leave gaps in our understanding of this group (Friedlander \& Levy, 1995). This limited information prevents an effective understanding of these algae in eutrophicated environments and "in situ" studies are necessary to clarify the physiological response of the algae to environmental parameters.

Successful seaweed cultivation in shrimp ponds is mainly related to the concentration of nutrients, type of cultivation and water flow (Buschmann et al., 2001). However, little is known on the effect of depth on the development and productivity of macroalgae in this environment. Previous studies indicate that seaweeds show different ecophysiological characteristics in response to depth changes during growth (Molloy \& Bolton, 1996; Xu \& Gao, 2008). Therefore, to explore this relationship and optimize cultivation conditions of G. birdiae, we investigated its growth at three depths.

\section{MATERIAL AND METHODS}

The study was carried out at an organic shrimp farm (PRIMAR) in the Northeast of Brazil $\left(06^{\circ} 18^{\prime} \mathrm{S}\right.$, $035^{\circ} 09^{\prime} \mathrm{W}$ ) in September and October 2006 (35 days). 
The total surface area in the farm ponds is 7.1 ha and their mean depth is $60 \mathrm{~cm}$. No animal feed, antibiotics, aerators or water circulation equipment were used.

The seaweeds were cultivated on modules comprising a square frame of PVC pipes of $1.0 \mathrm{~m}^{2}$ and polypropylene ropes (5 $\mathrm{mm}$ diameter). Each module contained four ropes in which ten $G$. birdiae seedlings $(15 \mathrm{~g})$ were inserted every $10 \mathrm{~cm}$, totaling $150 \mathrm{~g}$ of seaweed per rope. The modules were placed horizontally at three different depths (surface, $10 \mathrm{~cm}$ and $20 \mathrm{~cm}$ ) into shrimp pond. These depths were selected based on turbidity values observed in the ponds water. Every week, the seaweeds were removed of the ropes in order to determine their biomass and growth rate. Daily growth rate was calculated using the following formula: $\mathrm{SGR}=(100 \mathrm{ln}(\mathrm{Wt} / \mathrm{W} 0)) \mathrm{t}-1$, where SGR = specific growth rate (\% d-1); WO = initial wet weight; $\mathrm{Wt}=$ wet weight at time $\mathrm{t}(7$ days) based on Lobban \& Harrinson (1994).

Water salinity, temperature, $\mathrm{pH}$ and turbidity were measured weekly with Horiba U-10 water quality checker (CA, USA). Transparency was determined weekly with a Secchi disk and daily meteorological information on rainfall, evaporation, solar radiation and insolation were supplied by the Universidade Federal do Rio Grande do Norte meteorological station, and presented as week average. The nutrients $\left(\mathrm{NH}_{4}\right.$, $\mathrm{NO}_{3}, \mathrm{NO}_{2}$ and $\mathrm{PO}_{4}$ ) were sampled weekly (around the noon) and measured (in triplicate) by colorimetric analysis (FEMTO ${ }^{\circ}$ 600S) according to Strickland \& Parsons (1972). All water samples were filtered (GF/F WHATMAN $\left.{ }^{\mathrm{TM}}\right)$, kept in a cool box $\left(\approx 10^{\circ} \mathrm{C}\right)$ and analyzed after 4 hours.

Growth and abiotic data were first tested for normality (Kolmogorov-Smirnov test) and homocedasticity (Levene test), as suggested by Zar (1999). The Friedman test was used to determine significant differences between biomass values under different experimental depth. The Kruskal-Wallis analyses were performed to test significant differences $(p<0.05)$ comparing the temporal variation of environmental data.

Multiple regression analysis (backward stepwise) were carried out to establish correlations between the SGR and environmental variables at each depth. Linear correlations between observed and predicted values were fitted from the not explained variance by the models to express the best prediction of the SGR variable. As the requirements, equations with $p<0.05$ and normal residuals distribution were accepted. All analyses were performed using the software Statistica 7.0 (StatSoft $®$ ).

\section{RESULTS}

\section{Environmental Parameters}

The results on water quality and meteorological data are shown in Table 1. During cultivation the pond showed little variation in temperature $\left(26.7^{\circ} \mathrm{C}\right.$ to 28.5 ${ }^{\circ} \mathrm{C}$ ), a mean salinity of $31.2 \pm 2.0$ and slightly alkaline mean $\mathrm{pH}(8.1 \pm 0.3)$. Transparency did not exceed $33 \mathrm{~cm}$ and maximum turbidity was registered at the end of the experiment (116 NTU). The dissolved nutrient content of the water was high throughout the study. Ammonium $\left(\mathrm{NH}_{4}\right)$ showed the highest concentrations, ranging from 1.68 to $15.15 \mu \mathrm{mol} \mathrm{L}^{-1}$; nitrite $\left(\mathrm{NO}_{2}\right)$ ranged from 0.39 to $0.68 \mu \mathrm{mol} \mathrm{L}^{-1}$; nitrate $\left(\mathrm{NO}_{3}\right)$ between 0.14 and $1.03 \mu \mathrm{mol} \mathrm{L}^{-1}$ and orthophosphate $\left(\mathrm{PO}_{4}\right)$ ranged

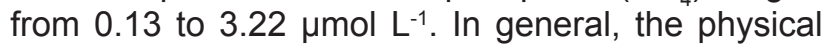
and chemical parameters values increased with the development of shrimp at the pound. The mean daily scores of the climatological variables precipitation (0.97 $\pm 2.17 \mathrm{~mm})$, evaporation $(6.17 \pm 0.93 \mathrm{~mm})$, insolation $\left(9.6 \pm 0.7 \mathrm{hr} \mathrm{d}^{-1}\right)$ and the accumulated solar radiation

Table 1 - Environmental parameters recorded during the study period (Kruskal-Wallis among the weekly data; $n=4)$.

\begin{tabular}{|c|c|c|c|c|}
\hline \multirow[t]{2}{*}{ Environmental variables } & \multirow[t]{2}{*}{ Range } & \multirow[t]{2}{*}{ Mean \pm SD } & \multicolumn{2}{|c|}{ Kruskal-Wallis } \\
\hline & & & H & $\boldsymbol{P}$ \\
\hline Temperature $\left({ }^{\circ} \mathrm{C}\right)$ & $26.7-28.5$ & $27.3 \pm 0.5$ & 31.50 & $<0.001$ \\
\hline Salinity $\left(g L^{-1}\right)$ & $27.9-33.9$ & $31.2 \pm 2.0$ & 32.76 & $<0.001$ \\
\hline Turbidity (NTU) & $35.0-116.0$ & $76.0 \pm 21.6$ & 25.14 & $<0.001$ \\
\hline $\mathrm{pH}$ & $7.5-8.5$ & $8.1 \pm 0.3$ & 32.28 & $<0.001$ \\
\hline Transparency (cm) & $25.0-33.0$ & $29.4 \pm 2.3$ & 17.87 & 0.002 \\
\hline Nitrite $\left(\mu \mathrm{mol} L^{-1}\right)$ & $0.39-0.68$ & $0.46 \pm 0.07$ & 32.48 & $<0.001$ \\
\hline Nitrate $\left(\mu \mathrm{mol} L^{-1}\right)$ & $0.14-1.03$ & $0.55 \pm 0.24$ & 29.30 & $<0.001$ \\
\hline Ammonium $\left(\mu \mathrm{mol} L^{-1}\right)$ & $1.68-15.15$ & $6.91 \pm 3.40$ & 32.66 & $<0.001$ \\
\hline Orthophosphate ( $\mu \mathrm{mol} L^{-1}$ ) & $0.13-3.22$ & $1.93 \pm 1.02$ & 32.67 & $<0.001$ \\
\hline Precipitation ( $\mathrm{mm})$ & $0.00-8.90$ & $0.97 \pm 2.17$ & 5.08 & 0.278 \\
\hline Evaporation ( $\mathrm{mm})$ & $4.00-7.70$ & $6.17 \pm 0.93$ & 20.22 & $<0.001$ \\
\hline Insolation $\left(h r d^{-1}\right)$ & $8.3-10.8$ & $9.6 \pm 0.7$ & 2.55 & 0.634 \\
\hline Accumulated solar radiation $\left(\mathrm{MJ} \mathrm{m}^{-2}\right)$ & $0.55-5.08$ & $2.84 \pm 1.02$ & 16.53 & 0.003 \\
\hline
\end{tabular}




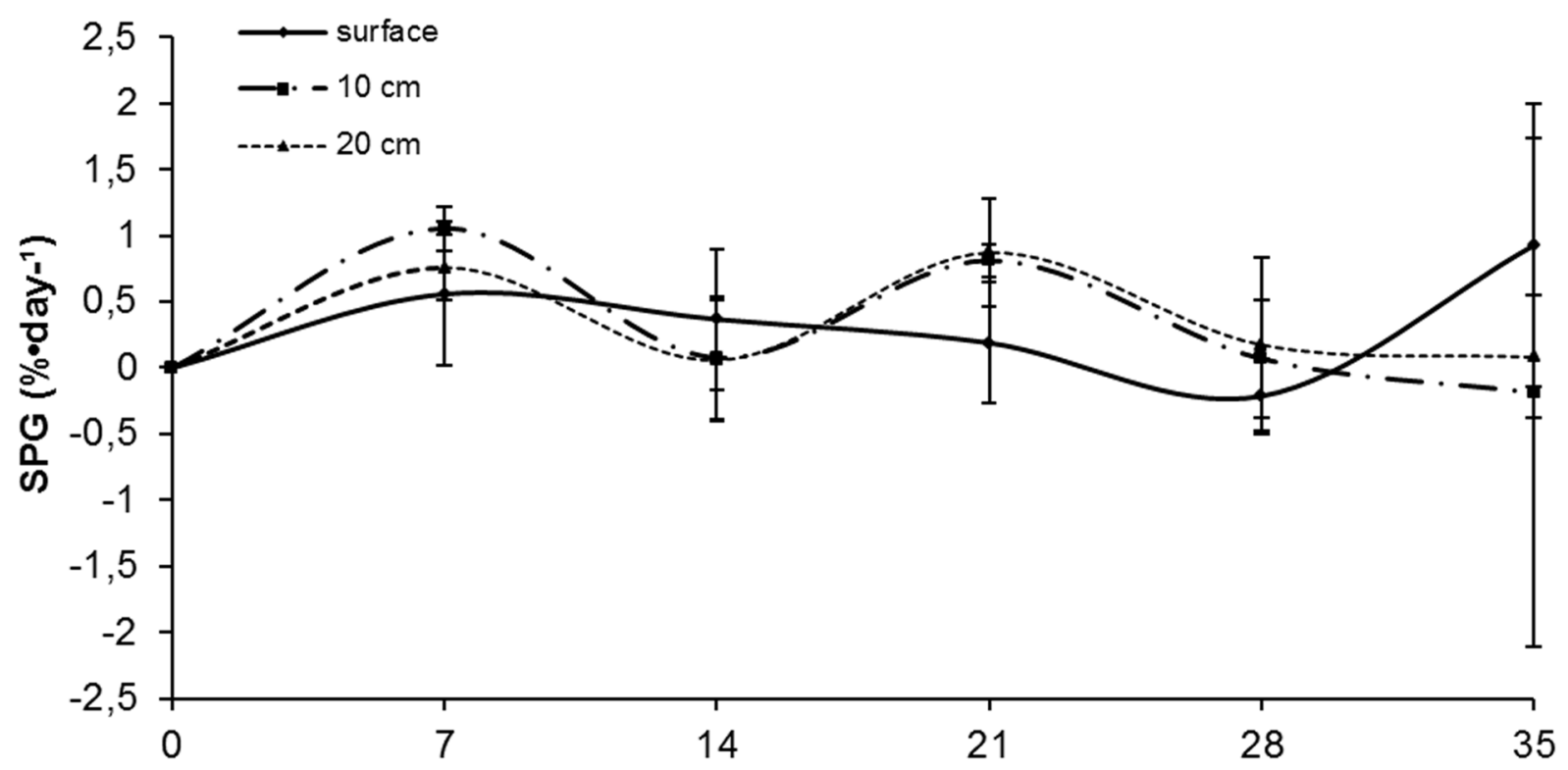

Figure 1 - Specific Growth Rate (\% d-1) of G. birdiae grown at different depths.

$\left(2.84 \pm 1.02 \mathrm{MJ} \mathrm{m}^{-2}\right)$ emphasize the tropical nature of the area, characterized by abundant and uniform sunlight (Table 1).

\section{Biomass and Growth Rate}

The biomass and growth of $G$. birdiae were significantly affected by the abiotic parameters inherent to the depth variation. The lowest biomass increase was obtained at the surface, increasing by $25.3 \%$ during the cultivation period. In this depth the lowest biomass recorded in each rope was $150 \mathrm{~g} \mathrm{(1^{ \text {st } }}$ week) and the highest $222 \mathrm{~g}$ ( $5^{\text {th }}$ week), with a mean value of $173.9 \pm 14.6 \mathrm{~g}$.

The seaweeds grown at $10 \mathrm{~cm}$ depth showed the highest biomass among those tested, increasing by $35.7 \%$ when compared to the initial inoculum. Its minimum biomass value in each rope was $171 \mathrm{~g} \mathrm{(1^{ \text {st } }}$ week) and maximum $227 \mathrm{~g}$ ( $5^{\text {th }}$ week) with a mean value of $193.6 \pm 18.2 \mathrm{~g}$ during the study period.

Biomass increased by $33.4 \%$ at $20 \mathrm{~cm}$. The lowest biomass value for seaweeds cultivated at this depth was $157 \mathrm{~g}$ ( $4^{\text {th }}$ week) and the highest was $208 \mathrm{~g}\left(1^{\text {st }}\right.$ week), with a mean value of $186.5 \pm 17.2 \mathrm{~g}$. Comparisons between cultivation depths show significant differences in biomass variation $(p<0.001)$.

The mean SGR at the surface, $10 \mathrm{~cm}$ and 20 $\mathrm{cm}$ in depth were $0.36 \pm 0.57 \% \mathrm{~d}^{-1}, 0.38 \pm 0.96 \% \mathrm{~d}^{-1}$ and $0.38 \pm 0.54 \% \mathrm{~d}^{-1}$ respectively. The lowest SGR recorded for seaweed at the surface was $-0.61 \% \mathrm{~d}^{-1}$ $\left(4^{\text {th }}\right.$ week) and the highest was $2.34 \% \mathrm{~d}^{-1}$ (5th week; Figure 1).

Two distinct growth periods were observed for seaweed maintained at $10 \mathrm{~cm}$ and $20 \mathrm{~cm}\left(1^{\text {st }}\right.$ and $3^{\text {rd }}$ week) and two periods of little or no growth $\left(2^{\text {nd }}\right.$ and $4^{\text {th }}$ week). The lowest SGR for the module at $10 \mathrm{~cm}$ was $-2.97 \% \mathrm{~d}^{-1}\left(5^{\text {th }}\right.$ week $)$ and the highest was $1.28 \% \mathrm{~d}^{-1}$ ( $1^{\text {st }}$ week). At a depth of $20 \mathrm{~cm}$ the SGR variation was $-0.59 \% \mathrm{~d}^{-1}\left(4^{\text {th }}\right.$ week $)$ and $1.28 \% \mathrm{~d}^{-1}\left(3^{\text {rd }}\right.$ week $)$.

Multiple regression analysis showed that temperature, salinity, $\mathrm{pH}$, orthophosphate and ammonium ion accounted for $67 \%$ of SGR variability in seaweeds kept at the surface (Table 2).

The SGR data obtained at this depth were positively correlated to the data from the simulated by the multiple regression $\left(R^{2}=0.67 ; r=0.82 ; p<0.05\right.$; Figure 2a). The SGR of seaweeds maintained at $10 \mathrm{~cm}$ was related to temperature, turbidity and $\mathrm{pH}$ (Table 2) and simulated SGR at this depth also correlated well with the values observed $\left(R^{2}=0.66 ; r=0.81 ; p<0.05\right)$ (Figure 2c). The results for algae at $20 \mathrm{~cm}$ confirm that turbidity, ammonium and orthophosphate can be used in the prediction equation (Table 2). The SGR at this depth correlated positively with that predicted by the regression $\left(R^{2}=0.62 ; r=0.78 ; p<0.05\right.$; Figure $\left.2 e\right)$. The relationship between the predicted and measured values showed that some of the growth rates were below the estimated values at the three depths tested (Figure $2 \mathrm{a}, 2 \mathrm{c}, 2 \mathrm{e})$. The residue analyses showed normal distribution at all three cultivation depths (requirement of multiple regression; Figure 2b, 2d, 2f).

\section{DISCUSSION}

The significant differences in biomass variations of $G$. birdiae at the three depths tested establish this variable as a relevant factor in seaweed growth. Although the water column of the pond was homog- 
Table 2 - Regression, coefficient, standard error, and p-valor for the variables in multiple regression related to SGR of G. birdiae as a dependent variable.

\begin{tabular}{lcccc}
\hline \hline Regression parameters & Sign & Coefficient & Std. Error & $\boldsymbol{p}$ \\
\hline Surface $(\boldsymbol{n}=\mathbf{3 5 )}$ & & & & \\
Constant & - & 12,649 & 4,284 & 0,006 \\
Temperature & + & 0,878 & 0,267 & 0,003 \\
Salinity & - & 0,088 & 0,028 & 0,005 \\
pH & - & 1,089 & 0,352 & 0,004 \\
Orthophosphate & - & 0,572 & 0,158 & 0,001 \\
Ammonium & + & 0,207 & 0,081 & 0,017 \\
$\mathbf{1 0}$ cm (n=34) & & & & \\
Constant & + & 16,105 & 2,326 & $<0,001$ \\
Temperature & - & 0,414 & 0,090 & $<0,001$ \\
Turbi dity & + & 0,013 & 0,003 & $<0,001$ \\
pH & - & 0,680 & 0,164 & $<0,001$ \\
& & & & \\
$\mathbf{2 0}$ cm (n=35) & & & & \\
Constant & + & 0,919 & 0,141 & $<0,001$ \\
Turbidity & - & 0,009 & 0,001 & $<0,001$ \\
Ammonium & + & 0,049 & 0,008 & $<0,001$ \\
Orthophosphate & - & 0,198 & 0,034 & $<0,001$ \\
\hline \hline
\end{tabular}

enous in physical and chemical composition, turbidity and light penetration significantly controlled seaweed growth. High turbidity in ponds is generally related to the amount of suspended material produced by shrimp culture, which decreases solar light penetration into the water column, restricting photosynthesis and seaweed growth (Marinho-Soriano et al., 2009).

The fact that $G$. birdiae was more productive at a depth of $10 \mathrm{~cm}$ suggests that it prefers environments with moderate irradiation. However, small variations in cultivation depth caused a decrease in algal growth. This is partly explained by the reduced light intensity owing to the high turbidity of the pond. Seaweeds grown at the surface gained less biomass. This low biomass may be due to dehydration and excess of light. The surface seaweeds were partly exposed to the air because of water evaporating from the ponds and wind effect. These caused water loss in the thallus and consequently a loss of biomass. Although there are no evaluations about the consequence of dehydration on Gracilaria growth, studies related to dehydration in Ulva reticulata stems, cultivated in fish pond waste, recorded losses of wet biomass (Msuya \& Neori, 2002). In addition, Yang et al., (2006) also recorded variations in seaweed growth between cultivation depths when growing Gracilaria lemaneiformis in eutrophicated water. This emphasizes that different depths in eutrophicated environments are a relevant factor in the productivity of Gracilaria.

Seaweeds generally have high growth rates when exposed to environments rich in nitrogen and phosphorous. However, they cannot tolerate nutrient rich environments for long periods, causing reduced productivity (Yu \& Yang 2008). G. birdiae showed positive SGR values at the surface, during the first 21 days of cultivation and at 10 and $20 \mathrm{~cm}$ depth on the 1 st and 3rd weeks. Although the values recorded during these periods were positive, they were lower than those found by other authors for the Gracilaria species in integrated cultivation (Nelson et al., 2001; Marinho-Soriano et al., 2002; Msuya \& Neori 2002; Chirapart \& Lewmanomont 2004). The modest values obtained in this study may also be related to limited water movement in the pond since no aerators or water circulation mechanisms were used. The direct association between water movement and nutrient absorption should be pointed out. In fact, Ryder et al. (2004) demonstrated that the lack of water movement significantly decreases growth rates of Gracilaria parvispora in ponds and lagoons in Hawaii.

Equations involving seaweed growth may be useful in studies about productivity. The equations used in this study included different environmental variables (temperature, salinity, $\mathrm{pH}$, orthophosphate, ammonium ion and turbidity) and the growth rate at each depth was significantly related to these factors. This fact emphasizes the influence of small depth variations on the growth rates of $G$. birdiae, as well as the interaction and specificity of environmental variables on the seaweeds development.

The regression equation showed higher prediction values $\left(R_{\text {surface }}^{2}=0.67 ; R^{2}{ }_{10 \mathrm{~cm}}=0.66 ; R^{2}{ }_{20 \mathrm{~cm}}=0.62\right)$ than those found by De Casabianca et al. (1997), which demonstrated that a 59\% SGR variation for $G$. bursapastoris was related to differences in light intensity and water temperature. They were also higher than those of 

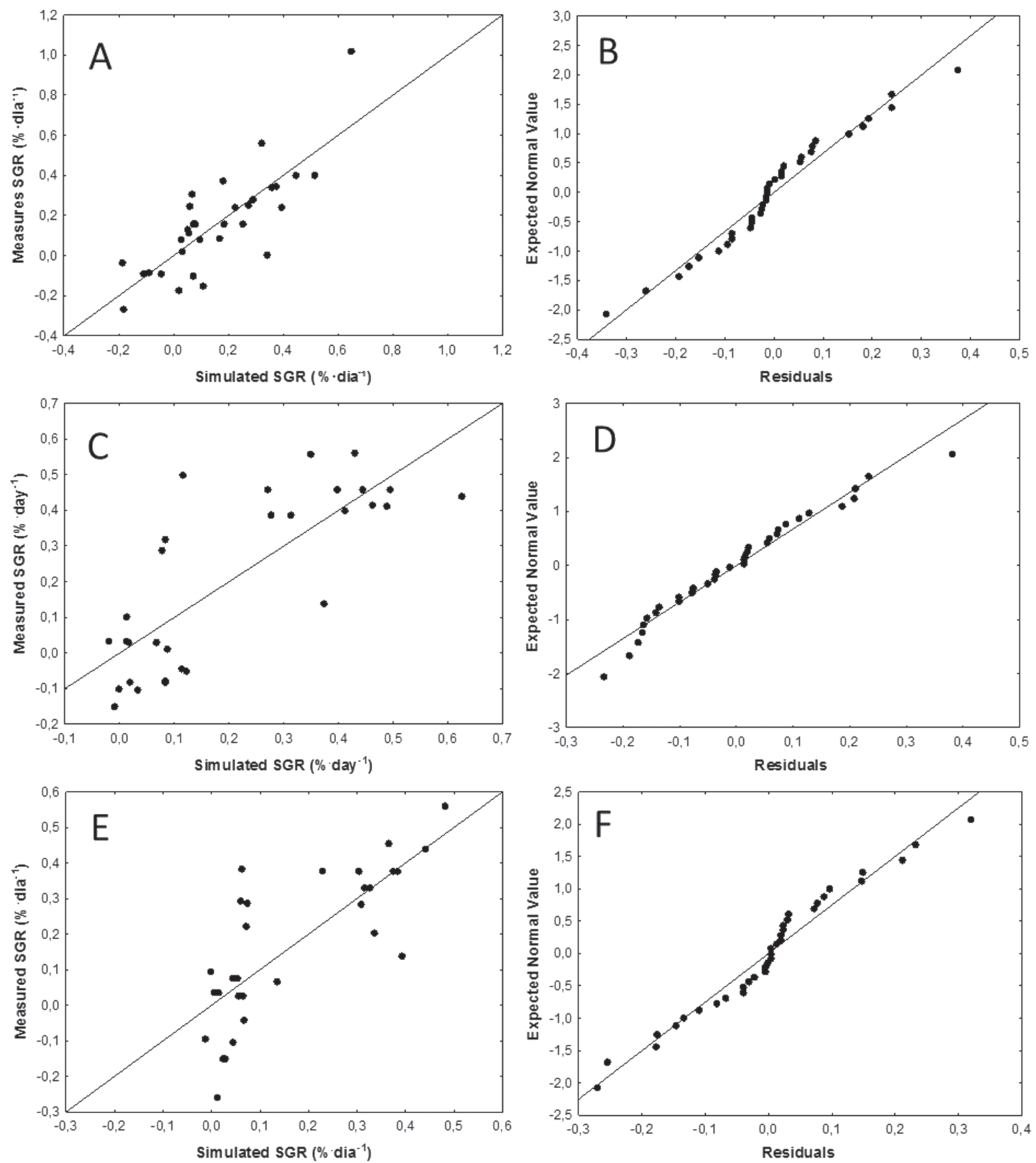

Figure 2 - Correlation between field and simulated data for G. birdiae cultivation and normal probability of residues for the estimated models: $(\mathrm{a}-\mathrm{b})$ surface; $(\mathrm{c}-\mathrm{d}) 10 \mathrm{~cm}$ deep; (e - f) $20 \mathrm{~cm}$ deep.

Marinho-Soriano et al. (2006), that proposed a growth model for $G$. birdiae relating $61 \%$ of the variation to salinity and the epiphyte biomass. Despite the high determination coefficient of the model, the relationship between predicted and observed values shows that some recorded growth values were lower than modelestimated amounts at the three depths tested. This may be due to biomass loss during the experiment. Furthermore, factors not measured such as herbivore, algal biomass losses, absorption kinetics and algal metabolism had some influence on algal development, affecting the accuracy of the growth equation. If these and other variables were included in future studies, they might improve the validity of the equation.

In summary, these results point out the significant effect of depth as an integrator of several parameters that can influence the growth of $G$. birdiae. It is an important factor to bear in mind when evaluating the cultivation conditions in shrimp pounds. 


\section{ACKNOWLEDGEMENTS}

This study was financed by the Conselho Nacional de Desenvolvimento Cientifico e Tecnológico (CNPq). The first author is grateful to the Fundação Coordenação de Aperfeiçoamento de Pessoal de Nível Superior (CAPES) for the scholarship awarded. Special thanks to Mr. Alexandre Wainberg for allowing the study to be carried out at PRIMAR shrimp farm.

\section{REFERENCES}

Angel, D.L; Verghese, S.; Lee, J.J.; Saleh, A.M.; Zuber, D.; Lindell, D. \& Simons, A. 2000. Impact of a net cage fishfarm on the distribution of benthic foraminifera in the northern Gulf of Elat (Aqaba, Red Sea). Journal of Foramineferal Research. 30:54-65.

Buschmann , A.H.; Troell, M. \& Kautsky N. 2001. Integrated algal farming: a review. Cahiers de biologie marine. 42: 83-90.

Buschmann, A.H.; Varela, D.A.; Hernández-González, M.C. \& Houvinen, P. 2008. Opportunities and challenges for the development of an integrated seaweed-based aquaculture activity in Chile: determining the physiological capabilities of Macrocystis and Gracilaria as biofilters. Journal of Applied Phycology. 20: 571-577.

Chirapart, A. \& Lewmanomont, K. 2004. Growth and production of Thai agarophyte cultured in natural pond using the effluent seawater from shrimp culture. Hydrobiologia. 512: 117-126.

Chopin, T.; Buschmann, A.H.; Halling, C.; Troell, M.; Kautsky, N.; Neori, A.; Kraemer, G.P.; ZertucheGonzález, J.A.; Yarish, C. \& Neefus, C. 2001. Integrating seaweeds into marine aquaculture systems: A key toward sustainability. Journal of Phycology. 37: 975-986.

De Casabianca, M.L.; Marinho-Soriano, E. \& Laugier, T. 1997. Growth of Gracilaria bursa-pastoris in a Mediterranean Lagoon: Thau, France. Botanica Marina. 40: 29-37.

Friedlander, M. \& Levy, I. 1995. Cultivation of Gracilaria in outdoor tanks and ponds. Journal of Applied Phycology. 7: 315-324.

Lobban, C.S. \& Harrison, P.J. 1994. Seaweed Ecology and Physiology. Cambridge University Press, United Kingdon, 366p.

Marinho-Soriano, E.; Morales, C. \& Moreira, W.S.C. 2002. Cultivation of Gracilaria (Rhodophyta) in shrimp pond effluents in Brazil. Aquaculture Research. 33: 1081-1086.

Marinho-Soriano, E.; Moreira, W.S.C. \& Carneiro, M.A.A. 2006. Some aspects of the the growth of
Gracilaria birdiae (Gracilariales, Rhodophyta) in an estuary in northeast Brazil. Aquaculture Intenational. 14: 327-336.

Marinho-Soriano, E.; Nunes, S.O.; Carneiro, M.A.A. \& Pereira, D.C. 2009. Nutrients removal from aquaculture wastewater using the macroalgae Gracilaria birdiae. Biomass and Bioenergy. 33: 327-331.

Molloy, F.J. \& Bolton, J.J. 1996. The effect of season and depth on the growth of Gracilaria gracilis at Lüderitz, Namibia. Botanica Marina. 39: 407-413. Msuya, F.E. \& Neori, A. 2002. Ulva reticulata and Gracilaria crassa: Macroalgae that can biofilter effluent from tidal fishponds in Tanzania. Western Indian Ocean Journal of Marine Science. 1 (2): 117-126.

Naylor, R.L.; Goldburg, R.J.; Primavera, J.H.; Kautsky, N.; Beveridge, M.C.M.; Clay, J.; Folke, C.; Lubchenco, J.; Mooney, H. \& Troell, M. 2000. Effect of aquaculture on world fish supplies. Nature. 405: 1017-1024.

Nelson, S.G.; Glenn, E.P.; Conn, J.; Moore, D.; Walsh, T. \& Akutagawa, M. 2001. Cultivation of Gracilaria parvispora (Rhodophyta) in shrimp-farm effluent ditchs and floating cages in Hawaii: a two-phase polyculture system. Aquaculture. 193: 239-248.

Nunes, A.J.P.; Gesteira, T.C.V. \& Goddard, S. 1997. Food ingestion and assimilation by the southern brown shrimp Penaeus subtilis under semiintensive culture in NE Brazil. Aquaculture. 149 (1-2): 121-136.

Ryder, E.; Nelson, S.G.; Mckeon, C.; Glenn, E.P.; Fitzsimmons, K. \& Napolean, S. 2004. Effect of water motion on the cultivation of the economic seaweed Gracilaria parvispora (Rhodophyta) on Molokai, Hawaii. Aquaculture. 238: 207-219.

Strickland, J.D.H. \& Parsons, T.R. 1972. A practical handbook of seawater analysis, Fisheries Research Board of Canada, Ottawa, 310p.

Troell, M.; Halling, C.; Neori, A.; Chopin, T.; Buschmann, A.H.; Kautsky, N. \& Yarish, C. 2003. Integrated mariculture: asking the right questions. Aquaculture. 226: 69-90.

Tyler, A.C. \& McGlathery, K.J. 2006. Uptake and release of nitrogen by the macroalgae Gracilaria vermiculophylla (Rodophyta). Journal of Phycology, 42: 515-525.

Xu, J. \& Gao, K. 2008. Growth, pigments, UVabsorbing compounds and agar yield of the economic red seaweed Gracilaria lemaneiformis (Rhodophyta) grown at different depths in the coastal waters of the South China Sea. Journal of Applied Phycology. 20: 681-686.

Yang, Y.F.; Fei, X.G.; Song, J.M.; Hu, H.Y.; Wang, G.C. \& Chung, I. K. 2006. Growth of Gracilaria 
lemaneiformis under different cultivation conditions and its effects on nutrient removal in Chinese coastal waters. Aquaculture. 254: 248-255.

Yu, J. \& Yang, Y.F. 2008. Physiological and biochemical response of seaweed Gracilaria lemaneiformis to concentration changes of $\mathrm{N}$ and $\mathrm{P}$. Journal of Experimental Marine Biology and Ecology. 367: 142-148.
Zar, J.H. 1999. Biostatistical Analysis,4th edn. PrenticeHall, NewJersey, 663p.

Submetido: Dezembro/2010

Revisado: Junho/2011

Aceito: Novembro/2011 